\title{
Hemolytical Profile Of Streptococcus Spfrom Nasal Swab Isolation At Traditional Farm In Bongkasa Village, Abiansemal Subdistrict, Badung Regency, Bali.
}

\author{
Ni Luh Made Siska Yanti ${ }^{1}$, I Wayan Suardana ${ }^{2}$, I Gusti Ketut Suarjana ${ }^{3}$ \\ 1Students of the Udayana University Faculty of Veterinary Medicine, \\ 2 Laboratory of Veterinary Public Health, Faculty of Veterinary Medicine, Udayana \\ University \\ *Corresponding Author: siska13yanti@gmail.com
}

\begin{abstract}
Streptococcus $s p$ is Gram positive cocci and aligned like chain. This bacteria can be found normally in upper respiratory tract. Streptococcus sp can be divided into two groups; able to hemolize blood and unable. B-hemolytic Streptococcus tend to be more pathogen than the others. Therefore this research about Streptococcus sp's hemolysis profile is very important. The samples of this research is an isolated swine nasal swab from a traditional pig farm in Bongkasa Village. 20 samples were used in this research. Samples were grown in Blood Agar media to find out the capability of bacteria for hemolizing blood. Catalase test used for differentiating Streptococcus $s p$ and Staphylococcus sp, followed by oxydase test after. Result of the research shows positive samples of Streptococcus sp divided by hemolysis profile is 11 isolates whereas 36,4\% isolates were Alfa hemolysis, 54,6\% were B hemolysis, and 9\% isolates were Gamma hemolysis.
\end{abstract}

Keywords: Streptococcus sp, hemolysis, swine's nasal

\section{I.INTRODUCTION}

Pigs are potential livestock animals to be bred with the aim of fulfilling the needs of animal protein in Indonesia. Since a long time ago, pigs have been used as a source of livelihood for Indonesian people [1]. Pigs are one of the livestock commodities that have great potential to be developed because they have their own advantages, including fast growth rates, many litter sizes and are quite efficient in using rations [2].

Streptococcus $s p$ is a Grampositive bacterium in the form of coccus and arranged in chains. These bacteria ferment carbohydrates, nonmotile, do not form spores, and are catalase-negative. [3]. Streptococcus sp bacteria are normal flora in the intestinal tract, cervicovaginal area, upper respiratory tract, skin and mucous membranes [4]. Outbreaks of Streptococcus $s p$ in pigs have been reported in Bali from May to July 1994.
This disease attacks pigs of all ages, genders and races. The rate of morbidity and mortality in pigs ranges from $51 \%$ and $38 \%$ while the case fatality rate reaches $75 \%$ [5].

Hemolysis is damage to red blood cells. In the world of microbiology hemolysis is used to classify certain microorganisms. The ability of bacteria to lyse erythrocytes is determined by substances in the form of extracellular proteins called hemolysin. Streptococcus $s p$ which has the ability to damage erythrocytes is classified as bacteria that are $\beta$-hemolysis, $\alpha$-hemolysis, and hemhemolysis [6].

This research was carried out in Bongkasa Village based on the investigation of the source of pigs that cause meningitis Streptococcus suis. Streptococcal meningitis cases occur in the village of Sibang Gede, Abiansemal District, Badung Regency, where it is 
known that the source of pigs comes from smallholder farms in Bongkasa Village.

\section{MATERIALS AND METHODS}

This study used 20 samples of swine nasal cavity swabs maintained by folk farmers in Bongkasa Village, Abiansemal District, Badung Regency, Bali. Bacterial isolation is carried out by means of samples taken from the field planted in blood media so that it is then incubated at $37{ }^{\circ} \mathrm{C}$ for $24-48$ hours in an anaerobic atmosphere with 5-7\% CO2 [7]. To find out the positive samples of Streptococcus $\mathrm{sp}$, the primary test was carried out: Gram stain, catalase test and oxidase test.

Gram staining begins with taking bacterial colonies and applying it to the surface of a glass object that has been stained with sterile distilled water, then flattened using osse. After that the preparations are aerated on a bunsen fire. After drying, the preparation is dripped with crystal violet for 1-2 minutes and then washed in running water. Then iodine drops for 1-2 minutes and washed in running water. $96 \%$ alcohol solvent (decolorizing) dripped for 30 seconds. After washing, safranin dye drops for 1-2 minutes and then washed in running water

\section{RESULTS AND ANALYSIS}

20 samples of swine nasal cavity swabs were isolated in Blood Agar media to grow bacteria. Then Gram stain, catalase test and oxidase test were carried out. Complete results of Gram staining from 35 samples as presented in Table 1.

The results of Gram staining contained two different isolates, namely 12 purple isolates with the form of coccus bacteria, and 23 purple isolates with the and dried. Observations were carried out under a microscope with the help of emersion oil at 1000x magnification [8].

The catalase test is carried out by taking 1 or 2 osse colonies and placed on the glass of the object, then adding 1 drop of $3 \% \mathrm{H} 2 \mathrm{O} 2$ solution and stirring evenly. The catalase positive bacteria are characterized by the formation of air bubbles in the colonies and surroundings. [8].

The oxidase test was carried out by centrifuge the sample on BHI media for 10 minutes. Then take the sediment on the tube using a sterile oil, put it on the oxidase test sheet, observe the color changes that occur in the oxidase sheet. [8].

Positive isolates of Streptococcus sp. then tested by blood hemolysis test by means of isolates planted in blood agar base media with the addition of 5\% sheep blood, then incubated at $37^{\circ} \mathrm{C}$ for $18-24$ hours. The appearance of clear zones around the colony after 18 hours of incubation at $37^{\circ} \mathrm{C}$ is considered a positive result of hemolysin production [9]. Data on the hemolysis profile of Streptococcus sp. Descriptive analysis is then presented in the form of tables or drawings.

form of coccus and suspended bacteria such as chains. This is similar to research conducted by Patterson which states that Streptococcus $s p$ is a Gram-positive bacterium in the form of coccus and arranged like a chain [3]. In Gram staining, Gram positive bacteria appear purple [10]. Purple Gram-positive bacteria caused by complex violet-iodine crystals are retained even though given a pale solution [7]. Furthermore, the 35 isolates were tested with the primary test namely catalase test and oxidase test. 
TABLE 1: GRAM STAINING RESULTS

\begin{tabular}{|c|c|c|c|c|}
\hline No & Sample Code & Gram & Form & Cell Structure \\
\hline 1. & TGN 1.1 & Positive & Coccus & Solitary \\
\hline 2. & TGN 1.2 & Positive & Coccus & Solitary \\
\hline 3. & TGN 2.1 & Positive & Coccus & Chain \\
\hline 4. & TGN 2.2 & Positive & Coccus & Chain \\
\hline 5. & TGN 3.1 & Positive & Coccus & Solitary \\
\hline 6. & TGN 3.2 & Positive & Coccus & Solitary \\
\hline 7. & TGN 4.1 & Positive & Coccus & Solitary \\
\hline 8. & TGN 4.2 & Positive & Coccus & Solitary \\
\hline 9. & TGN 5.1 & Positive & Coccus & Solitary \\
\hline 10. & TGN 5.2 & Positive & Coccus & Solitary \\
\hline 11. & TGN 6.1 & Positive & Coccus & Chain \\
\hline 12. & TGN 6.2 & Positive & Coccus & Chain \\
\hline 13. & TGN 7.1 & Positive & Coccus & Chain \\
\hline 14. & TGN 7.2 & Positive & Coccus & Solitary \\
\hline 15. & TGN 7.3 & Positive & Coccus & Solitary \\
\hline 16. & TGN 8.1 & Positive & Coccus & Solitary \\
\hline 17. & TGN 8.2 & Positive & Coccus & Chain \\
\hline 18. & TGN 8.3 & Positive & Coccus & Chain \\
\hline 19. & TGN 9.1 & Positive & Coccus & Chain \\
\hline 20. & PN 10.1 & Positive & Coccus & Solitary \\
\hline 21. & PN 10.1 & Positive & Coccus & Chain \\
\hline 22. & PN 11.1 & Positive & Coccus & Chain \\
\hline 23. & PN 11.1 & Positive & Coccus & Chain \\
\hline 24. & PN 12.1 & Positive & Coccus & Chain \\
\hline 25. & PN 12.2 & Positive & Coccus & Chain \\
\hline 26. & PN 12.3 & Positive & Coccus & Chain \\
\hline 27. & PN 13.1 & Positive & Coccus & Chain \\
\hline 28. & PN 13.2 & Positive & Coccus & Chain \\
\hline 29. & PN 14.1 & Positive & Coccus & Chain \\
\hline 30. & PN 15.1 & Positive & Coccus & Chain \\
\hline 31. & PN 16.1 & Positive & Coccus & Chain \\
\hline 32. & PN 17.1 & Positive & Coccus & Chain \\
\hline 33. & PN 18.1 & Positive & Coccus & Chain \\
\hline 34. & BKN 19.1 & Positive & Coccus & Chain \\
\hline 35. & BKN 20.1 & Positive & Coccus & Chain \\
\hline
\end{tabular}

Catalase test is used to determine the nature of bacteria in producing the enzyme catalase [11] and distinguishes the species Staphylococcus sp. and Streptococcus sp [12]. Positive catalase is indicated by the presence of gas bubbles (O2) produced by the Staphylococcus genus while the negative catalase test does not produce gas bubbles [13]. In this study there were 11 samples which showed negative catalase test. Based on research from Toelle and Lenda the results of the negative catalase test were Streptococcus sp [13].

Of the 11 bacteria that showed negative catalase, an oxidase test was carried out. Oxidase test results showed positive oxidase, which is a violet color change on oxidase paper. Oxidase test serves to determine the presence of 
cytochrome oxidase which can be found in certain bacteria. Facultative aerobic and anaerobic bacteria have cytochrome oxidase and oxygen enzymes as their electron receptors so that the test will give positive results as indicated by violet discoloration in the oxidase test strip and indicates that the bacteria are non-enteric bacteria [14]. This is consistent with a statement from Toelle and Lenda which states that Streptococcus sp. showed a positive oxidase test [13].

TABLE 2: CATALASE TEST AND OXIDASE TEST RESULTS

\begin{tabular}{cccc}
\hline No & Sample Code & Catalase Test & Oxidase Test \\
\hline 1. & TGN 2.2 & Negative & Positve \\
2. & TGN 3.1 & Negative & Positve \\
3. & TGN 3.2 & Negative & Positve \\
4. & TGN 4.1 & Negative & Positve \\
5. & TGN 5.2 & Negative & Positve \\
6. & TGN 6.2 & Negative & Positve \\
7. & TGN 7.1 & Negative & Positve \\
8. & TGN 8.3 & Negative & Positve \\
9. & PN 10.1 & Negative & Positve \\
10. & PN 14.2 & Negative & Positve \\
11. & PN 16.2 & Negative & Positve \\
\hline
\end{tabular}

Furthermore, of the 11 isolates that have been known to be Streptococcus sp. replanted in the blood agar media to find out the hemolysis profile

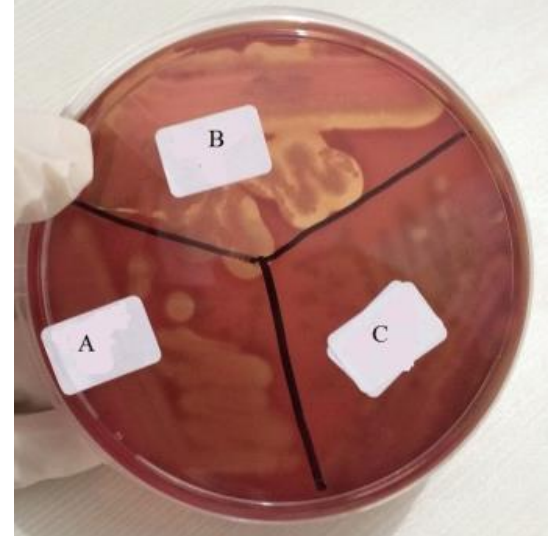

Figure 1: Hemolysis Test Results: $\beta$ hemolysis is shown in Figures $\mathrm{A}$ and $\mathrm{B}$ and $\alpha$ hemolysis is shown in Figure $\mathrm{C}$.

From the results of the Hemolysis test on table 3 found 6 isolates formed $\beta$ Hemolysis, 4 isolates formed $\alpha$ Hemolysis and 1 isolate formed $\gamma$ Hemolysis. The percentage of positive samples of Streptococcus $s p$ based on its hemolysis properties, as much as $36.4 \%$ isolates were $\alpha$ hemolysis, $54.6 \%$ isolates were $\beta$ hemolysis and $9 \%$ isolates were $\gamma$ hemolysis.

Hemolysin production from Streptococcus sp. can be seen using the blood hemolysis test. Hemolysin production is determined based on the presence of hemolysis zones formed by isolates [9]. In Streptococcus sp. the size of the hemolysis zone is several times the diameter of the germ colony [15]. From this isolation, 11 colonies of bacteria producing hemolysin were divided into 3 groups, namely $\alpha$ hemolysis, $\beta$ hemolysis and $\gamma$ hemolysis according to research conducted by McKane and Kandel [6].

Bacteria that produce hemolysin in solid media so that blood will show discoloration in the bacterial growth zone. 
Bacteria that have the ability to damage erythrocytes show clear / clear zones around the growth of colonies on the blood agar medium and are classified as $\beta$ hemolysis bacteria and when around the colony growth shows the zone that is not clear is included in the group of $\alpha$ hemolysis bacteria and bacteria that do not have the ability to damage erythrocytes grouped into non-hemolytic or hemhemolytic groups [6].

The bacteria that make up the most hemolysis $\beta$ found in this study are caused by the use of sheep's blood. In accordance with Ellen et al statement that sheep blood defibrinated is the best material for making blood agar media and will provide a perfect zone of hemolysis [16].

TABLE 3: RESULTS OF STREPTOCOCCUS SP. ISOLATE HEMOLYSIS TEST.

\begin{tabular}{ccc}
\hline No & Sampel Code & Hemolysis \\
\hline 1. & TGN 2.2 & $\beta$ \\
2. & TGN 3.1 & $\alpha$ \\
3. & TGN 3.2 & $\beta$ \\
4. & TGN 4.1 & $\alpha$ \\
5. & TGN 5.2 & $\beta$ \\
6. & TGN 6.2 & $\beta$ \\
7. & TGN 7.1 & $\alpha$ \\
8. & TGN 8.3 & $\gamma$ \\
9. & PN 10.1 & $\alpha$ \\
10. & PN 14.2 & $\beta$ \\
11. & PN 16.2 & $\beta$ \\
\hline
\end{tabular}

Streptococcus on the blood agar medium of sheep forming $\beta$ hemolysis is Streptococcus pyogenes, S. Agalactiae, S. equi, $S$. canis. While streptococci that form $\alpha$ or $\gamma$ hemolysis are S. mutans, $S$. sanguis, $S$. salivarius, $S$. mitior, $S$. anginosus (formerly $S$ milleri), $S$. constellatus, S. intermedius, S. suis and $S$. iniae [17].

Outbreaks of $\beta$ hemolysis streptococci have occurred in Bali in 1994 which attacked pigs and monkeys caused by Streptococcus equi zooepidemicus subspecies and known as Streptococcal meningitis [5].

\section{CONCLUSION}

Based on the results of the research conducted, it can be concluded that: The number of positive samples of Streptococcus $s p$ in Bongkasa Village, Abiansemal District, Badung Regency, Bali based on the hemolysis properties of 11 of 35 isolates $(31.4 \%)$ with details of 4 of 11 (36 4\%) isolates were $\alpha$ hemolysis, as many as 6 of $11(54.6 \%)$ isolates were $\beta$ hemolysis and 1 of $11(9 \%)$ isolates were $\gamma$ hemolysis.

\section{SUGGESTION}

Further research is needed to find out the types of Streptococcus sp that have been isolated in this study.

\section{ACKNOWLEDGEMENT}

On this occasion the researchers thanked the pig farmers in Bongkasa Village, Abiansemal District, Badung Regency, Bali who had helped the smoothness and ease of taking research samples.

\section{REFERENCES}

[1] Sampurna, I. P., Suatha, I. K., Menia, Z. 2011. Pola Pertumbuhan Dimensi Panjang dan Lingkar Tubuh Babi Landrace. Majalah Ilmiah Peternakan, 1(1):18-21. 
[2]

Sinaga, S.Silalahi,

M.2002.Performans Produksi Babi akibat Tingkat Pemberian Manure Ayam Petelur sebagai Bahan Pakan Alternatif.Jitv Vol. 7( 4): 207-213

[3] Patterson, M.J. 1996. Streptococcosis in medical microbiology,4 Ed

[4] Suardana, I.W.2016. Buku Ajar Zoonosis; Penyakit Menular dari Hewan ke Manusia.Kanisius Yogyakarta.

[5] Dharma, D.M.N., Dartini,N.L., Soeharsono, Supartika,E., Dibia, N. 1994. Wabah Streptococcal Meningitis pada Babi dan Kera di Bali. Bulletin Sain Veteriner 10 (26): 110- 121

[6] McKane, L., Kandel,J. 1998. Microbiology. Essentials and Applications. 2nd ed. McGrawHill, Inc. Philadelphia.

[7] Hidayat,R.,

Alhadi,F.2012.Identifikasi

Streptococcus Equi Dari Kuda Yang Diduga Menderita Strangles.Jurnal Ilmu Pertanian Indonesia (Jipi) Vol. 17 (3): 199203

[8] Prescott, H. K. 2002. Laboratory Exercise in Microbiology. The Mc Gram Hill Companies. New York. pp. 126-139.

[9] Osek, J. 2004. Phenotypic and genotypic characterization of Escherichia coli O157 strains isolated from human, cattle, and pigs. Vet. Med-Czech. 9:317-326.

[10] Lindawati,S.A.,

Suardana,I.W.2016.Isolasi dan Identifikasi Spesies Bakteri Asam Laktat Penghasil Senyawa Antimikrob Asal Kolon Sapi Bali.Jurnal Veteriner .Vol. 17 (4 ): 576-6581
[11] Kismiyati, Subekti, S., Kusdarwati,R.2009. Isolasi dan Identifikasi Bakteri Gram Negatif pada Luka Ikan Maskoki (Carassius Auratus) Akibat Infestasi Ektoparasit Aspergilus

[12] Todar, K. 2005. Todar's Online Textbook of Bacteriology, Staphylococcus. Diakses melalui http://textbookbacteriology.net/ stap_2.html

[13] Toelle,

N.N.,Lenda,V.2014.Identifikasi dan Karakteristik Staphylococcus Sp. dan Streptococcus Sp. dari Infeksi Ovarium Pada Ayam Petelur Komersial. Jurnal Ilmu Ternak.Vol. 1( 7):32 - 37

[14] Macfaddin,J.F.,

Editor.2000.biochemical tests for identification of medival bacteria . $3^{\text {rd }}$ ed Philadelphia: Lippincott williams \& wilkins.451-3

[15] Hall, K.K., Lyman,A.J.A. 2006. Updated Review of Blood Culture Contamination. Clin MicrobiolRev. 19: 788-802.

[16] Ellen,Y., Benjamin,A., Pinsky, Niaz, B., Ellen, J.B. 2009. Hair Sheep Blood, Citrated or Defibrinated, Fulfills All Requirements of Blood Agar for Diagnostic Microbiology Laboratory Tests. PLOS ONE. 4:1-8

[17] Larry M., Bush, M.D., Maria, T., Perez, M.D. 2017 . Merck Manuals. Diakses melalui:https://www.merckmanuals .com/professional/infectiousdiseases/gram-positivecocci/streptococcal-infections. Tanggal akses 3 Mei 2018. 